\title{
Resources on the Nett Information Seeking Behavior
}

Compiled by Anne Wade and Chris Bober, Concordia University, Montreal, Quebec

\section{History and Overview of Information Seeking Behavior}

Wilson, T.D. (2000). Human Information Behavior. [Electronic version]. Informing Science, 5(2), 49-55. Retrieved December 22, 2005, from http://inform.nu/Articles/Vol3/v3n2p49-56.pdf

Wilson reviews the origins and the evolution of human information seeking behavior research, including the shift beginning in the 1980's towards studies that focus on the user and away from those that concentrated on the design of the system.

\section{Literature Reviews on Information Seeking Behavior}

Martzoukou, Konstantina. (2005, January). A review of web information seeking research: Considerations of method and foci of interest. Information Research, 10(2). Retrieved December 21, 2005, from http://informationr.net/ir/10-2/paper215.html

The author reviews studies on Web information seeking research, and posits that they lack a consistent methodological approach. Guidelines for future research are presented for "it is important that individual Web information seeking behavior is studied from all its multiple facets, such as experience, information need, affective and cognitive characteristics, and socially and culturally determined traits."

Tenopir, C. (2003). Use and Users of Electronic Library Resources: An Overview and Analysis of Recent Research Studies. Retrieved December 22, 2005, from Council on Library and Information Resources Web site: http://www.clir.org/pubs/reports/pub120/pub120.pdf

This report reviewed over 200 research studies published between 1995 and 2003 that focused on user behavior with electronic library resources. Its purpose is "to help librarians identify reliable research studies, to provide a synopsis of the good studies, and to present an analysis of conclusions." The synthesis of the studies provides a useful planning document as it presents a "full picture of what users actually do, why they do it, what they would prefer, and what they are likely to do in the future."

\section{Studies on the Information Seeking Behavior of Students}

Bilal, D., and Kirby, J. (2002). Differences and similarities in information seeking: Children and adults as web users. Information Processing and Management, 38, 649-670. Retrieved January 1, 2006, from https://206.191.28.118/docushare/dsweb/Get/Document-1535/Bilal_Kirby_2002_child_adult_ websearch.pdf

This study examined the success of information seeking behaviors of seventh-grade science students and graduate students in information science in using the Yahooligans! web search engine/directory. Bilal and Kirby compared a number of factors related to the cognitive, affective and behaviors of the two groups. Their findings revealed that " $89 \%$ of the graduate students found the correct answer to the search task as opposed to $50 \%$ of the children. Based on the [Web Traversal] Measure, graduate students' weighted effectiveness, efficiency, and quality of the Web moves they made were much higher than those of the children. Regardless of success and weighted scores, however, similarities and differences in information seeking were found between the two groups." The authors include a section on implications 
for web training and system design.

Navarro-Prieto, R., Scaife, M., and Rogers, Y. (1999, June). Cognitive strategies in web searching. Proceedings of the $5^{\text {th }}$ Conference on Human Factors and the Web. Retrieved December 22, 2005, from http://zing.ncsl.nist.gov/hfweb/proceedings/navarro-prieto/index.html

The purpose of this study was to isolate and to analyze the significance of different variables in Web searching: the users' experience and cognitive strategies; the type of searching task; how the information is presented; the degree of interactivity between the system and the user. A theoretical model of web searching behavior for both novice and experienced users is presented.

OCLC Online Computer Library Center. (2002, June). OCLC White Paper on the Information Habits of College Students: How Academic Librarians Can Influence Students' Web-Based Information Choices. Retrieved December 22, 2005, from http://www5.oclc.org/downloads/community/ informationhabits.pdf

This paper reports findings of an OCLC commissioned survey conducted in December, 2001, on webbased information habits of over 1000 college and university students in the $\mathrm{U}$. S. The survey revealed that academic libraries' Web sites and the resources that they offer are highly valued by students for their accuracy and for the timeliness of the information included within them. It suggests that academic libraries should capitalize on this finding and that they should continue to work towards improving their promotional, instructional and accessibility efforts in order to best meet students' information needs.

Pew Internet and American Life Project. (2002, September 15). The Internet Goes to College: How Students are Living in the Future with Today's Technology. Retrieved December 22, 2005 from http://www.pewinternet.org/pdfs/PIP_College_Report.pdf

A large scale survey on the impact of the Internet on the daily lives of undergraduate and graduate students at two year and four year public and private colleges and universities in the United States was conducted between March and June, 2002. The subsequent report was based on survey responses from over two thousand students at twenty seven schools nationwide. The findings revealed that students have integrated the Internet into the very fabric of their academic and their social lives. Nearly seventy-five percent of college students said that they used the Internet more than they use the library to look for information and only nine percent said that they used the library more. It is believed that upon graduation, the Internet will continue to play a vital role in both their information seeking behavior and in their leisure and entertainment seeking behavior.

Seiden, P., Szymborski, K., and Norelli, B. (1997). Undergraduate students in the digital library: Information seeking behavior in a heterogeneous environment. Paper presented at the ACRL National Conference (Nashville, TX). Retrieved January 3, 2006, from http://www.ala.org/ala/acrlbucket/ nashville1997pap/seidenszymborski.htm

The authors report preliminary findings from their study of information seeking behavior of sixty undergraduate students at Skidmore College (NY). Data were collected through a series of individual and group interviews with students who ranged in their level of library expertise. Findings revealed that the digital library influences students' information seeking behavior in a number of areas. For example, "Students driven by time pressures and seduced by the convenience of one stop shopping increasingly rely on full-text and the Web to the exclusion of other resources; Students frequently start and end their research at the computer; (2) students are have increasing difficulty discerning critical differences among various sources of information because they are available via a single computer and a uniform interface or browser; (3) the "digital library" does not remedy a poor understanding of the overall information environment; rather, the heterogeneity of the environment exaggerates and magnifies these problems; (4) on the positive side, the availability of "unpublished information" on the Web and virtual "invisible colleges" via newsgroups and listservs allows students to have access to information sources previously only tapped by faculty; [and] (5) because students seek help from librarians both at the beginning and in the middle of their searches, the help seeking provides an opportunity for education about not only the system, but information seeking strategies in general." Implications for future research are addressed. 


\section{Studies on the Information Seeking Behavior of Faculty}

King, D.W., Tenopir, C., Montgomery, C.H., and Aerni, S.E. (2003, October). Patterns of journal use by faculty at three diverse universities. D-Lib Magazine, 9(10). Retrieved December 22, 2005, from http://www.dlib.org/dlib/october03/king/10king.html

This is a report on journal readership surveys conducted on faculty at three American universities. Their purpose was to see how the transition to electronic journal collections was impacting on faculty readership patterns, the "extent of journal reading, source of articles read, the extent to which print and electronic formats are used and how readers learned about the articles." The authors also utilized existing studies on faculty reading trends covering a twenty five year period. The surveys revealed that faculty's personal journal subscriptions have decreased while their use of library journal collections have increased. This was attributed to the increased availability of e-journals and of library electronic journal collections, as well as to the increase in online bibliographic searching for journal articles.

\section{Studies on Information Seeking Behavior}

Bates, M.J. (2002). Toward an integrated model of information seeking and searching. Keynote address at the Fourth International Conference on Information Needs, Seeking and Use in Different Contexts (Lisbon, Portugal, September 11-13, 2002). Retrieved January 4, 2006, from http://www.gseis. ucla.edu/faculty/bates/articles/info_SeekSearch-i-030329.html

Bates suggests that because much of the current research on information seeking research is on the social and cultural context of human interaction with information, it is incomplete. Bates' research attempts to "provide a single model that incorporates both information seeking and searching within it, and to integrate the social and cultural with the underlying biological and physical anthropological layers of human experience with respect to information seeking and searching."

Choo, C.W., \& Marton, C. (2003). Information seeking on the web by women in IT professions. Internet Research, 13(4), 267-280. Retrieved January 1, 2006, from http://choo.fis.utoronto.ca/ FIS/ ResPub/InternetR/default.html

Choo and Marton, from the Faculty of Information Studies, University of Toronto, and the School of Library, Archival and Information Studies, UBC respectively, analyze the web information seeking behavior of 24 women from various IT professions, using a behavioral model for web information seeking. Data were collected using a custom-developed WebTracker software and through interviews. Their findings revealed "that a behavioral approach that links information seeking modes (goals and reasons for browsing and searching) to moves (actions used to find and view information) may be helpful in understanding Web-based information seeking."

Digital Library Federation and The Council on Library and Information Resources. (2002). Dimensions and Use of the Scholarly Information Environment. Retrieved December 22, 2005, from http://www. diglib.org/pubs/scholinfo/

Academic library usage patterns are changing as their patrons' information needs gravitate towards the web. In order to better comprehend changes in library usage patterns, a large scale survey (over three thousand respondents) of undergraduates, graduate students, and faculty members was conducted at three types of American institutions: public universities, private doctoral research institutions, and liberal arts colleges. The primary goal of the survey questionnaire was "to collect data on the relevance of existing and possible future services as well as on student and faculty perceptions of the library's value in the context of the scholarly information environment." It is hoped that the survey's findings can be used by libraries to help plan information services to meet the current and future needs of faculty and students. 
Heinström, J. (2003). Five personality dimensions and their influence on information behaviour. Information Research, 9(1) paper 165. Retrieved January 1, 2006, from http://Informationr.net/ir/9-1/ paper165.html

Heinström emphasizes "the importance of considering psychological mechanisms for a thorough understanding of users of information services. The focal point is the relation between personality and information seeking which is explored through a quantitative analysis of 305 university students' personality traits and information habits. It is shown that information behaviour could be connected to all the personality dimensions tested in the study - neuroticism, extraversion, openness to experience, competitiveness and conscientiousness. Possible explanations for these relations are discussed. It is concluded that inner traits interact with contextual factors in their final impact on information behaviour." Includes an extensive bibliography.

Järvelin, K. \& Wilson, T.D. (2003). On conceptual models for information seeking and retrieval research. Information Research, 9(1) paper 163. Retrieved on January 3, 2006, from http://Information R.net/ir/9-1/paper163.html

Järvelin and Wilson discuss the functions of conceptual models in scientific research, focusing on the information seeking and retrieval research. They address such questions as "What kind of models are there and in what ways may they help the investigators? What kinds of models are needed for various purposes?" They search for models that provide guidance in setting research questions, and formulating hypotheses. The authors use as an example one analytical model of task-based information seeking and discuss its contribution to the development of the research area. Includes an extensive bibliography.

\section{Links to Sites}

American Society for Information Science \& Technology (ASIS\&T). (2005, December 20). Special Interest Group Information Needs Seeking and Use (USE). Retrieved December 22, 2005, from http:// www.asis.org/SIG/SIGUSE/

SIG USE membership targets individuals "concerned with people's behavioral and cognitive activities as well as their affective states as they interact with information." A link to Publications includes a bibliography of research studies published between 2000 and 2002 by SIG USE members. The site links to live webcasts about topics in human information behavior, and information about their symposium.

Bates, M. (2000). Bates' Bibliography of Works on Information Seeking, Indexing, and Information Retrieval System Design. Retrieved January 4, 2006, from http://www.gseis.ucla.edu/faculty/bates/bibintro.html

A comprehensive bibliography of material, covering the last twenty years or so, related to Bates' research interests-namely, information seeking, indexing and information retrieval organized by her own classification system.

Compilers' note: Text that is enclosed within quotations marks has been taken directly from the source document.

Chris Bober is the Education Librarian at Concordia University Libraries. Email: boberc @alcor.concordia.ca

Anne Wade is manager of the Centre for the Study of Learning and Performance and has taught in the Information Studies Program at Concordia University for ten years. Email: wada@education.concordia.ca 